DE

M E D I C I N A

T R O P I C A L

$\mathrm{DE}$

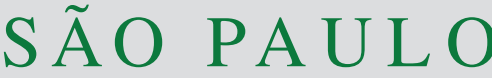

JOURNAL OF THE SÃO PAULO INSTITUTE OF TROPICAL MEDICINE

'Universidade Federal de Goiás, Regional Jataí, Unidade Acadêmica Especial de Ciências da Saúde, Laboratório de Parasitologia, Jataí, Goiás, Brazil

2Universidade Federal de Uberlândia, Instituto de Ciências Biomédicas, Departamento de Imunologia, Microbiologia e Parasitologia, Uberlândia, Minas Gerais, Brazil

${ }^{3}$ Universidade Federal de Goiás, Regional Jataí, Unidade Acadêmica Especial de Ciências Exatas, Laboratório de Química, Jataí, Goiás, Brazil

Correspondence to: Rosângela Maria Rodrigues

Universidade Federal de Goiás, Regional Jataí, Unidade Acadêmica Especial de Ciências da Saúde, Laboratório de Parasitologia. Campus Cidade Universitária, BR. 364, Km 195, n 3800, CEP 75801-615, Jataí, GO, Brazil

Tel: +55 6496232172

E-mail: rosismaria@yahoo.com.br

Received: 23 April 2019

Accepted: 25 September 2019

\section{In vitro ovicidal and larvicidal activity of Carica papaya seed hexane extract against Strongyloides venezuelensis}

\author{
Eduardo Ramos Martins Cabral ${ }^{\circledR 1}$, Dayane Moraes ${ }^{(1}$, Marcelo Arantes \\ Levenhagen $^{(1)}$, Ricardo Alexandre Figueiredo de Matos ${ }^{\circledR}{ }^{3}$, Julia Maria \\ Costa-Cruz $^{(1)}$, Rosângela Maria Rodrigues ${ }^{(1)}$
}

\section{ABSTRACT}

Strongyloidiasis is a human parasitic disease caused by the helminth Strongyloides stercoralis whose treatment is particularly difficult in immunosuppressed patients due to their low responsiveness to conventional therapy. Carica papaya and its isolated compounds benzyl isothiocyanate, carpaine and carpasemine are promising compound for the treatment of Strongyloides infections due to their anthelmintic action. This study aims to examine the in vitro ovicidal and larvicidal activity of C. papaya seed hexane extract against Strongyloides venezuelensis, using egg hatching tests and larval motility tests as efficiency markers. The crude extract at the concentrations of $566-0.0566 \mathrm{mg} / \mathrm{mL}$ or the control with albendazole $(0.025 \mathrm{mg} / \mathrm{mL})$ and negative controls (water and PBS) were incubated with an equal volume of egg suspension ( \pm 50 specimens) followed by counting of the specimens after $48 \mathrm{~h}$. The same extract and dilutions were added to L3 larvae suspensions ( \pm 50 specimens) followed by analysis of larvae viability after 24,48 , and $72 \mathrm{~h}$. The extract inhibited egg hatching with high efficiency at concentrations of $56.6 \mathrm{mg} / \mathrm{mL}(95.74 \%)$ and $5.66 \mathrm{mg} / \mathrm{mL}(92.16 \%)$. At the concentrations of $566 \mathrm{mg} / \mathrm{mL}(100 \%)$ and $56.66 \mathrm{mg} / \mathrm{mL}(97.32 \%)$, the extract inhibited larval motility as effectively as ivermectin $(0.316 \mathrm{mg} / \mathrm{mL} ; 100 \%)$, and more effectively than the other dilutions and the negative controls. The larvicidal effect depended on the extract concentration, but not on the treatment period. Therefore, $C$. papaya seed hexane extract has anthelmintic potential against $S$. venezuelensis and is a promising compound for the development of phytotherapies to treat strongyloidiasis.

KEYWORDS: Carica papaya. Seed extract. Egg hatching test. Larval motility test. Anthelmintic activity. Strongyloidiasis. Strongyloides stercoralis. Strongyloides venezuelensis.

\section{INTRODUCTION}

Strongyloides sp. is an intestinal parasite that can cause potentially fatal disseminated infections in immunocompromised patients, such as those under corticosteroids therapy, malnourished patients, or those presenting with concomitant underlying diseases caused by the human immunodeficiency virus (HIV) and the human lymphotropic T-virus (HTLV) ${ }^{1}$. The current synthetic drugs prescribed for the treatment of strongyloidiasis are albendazole, thiabendazole, mebendazole and ivermectin ${ }^{2,3}$. The low efficacy in long-term treatments, malabsorption in cases of disseminated disease and undesirable, sometimes serious adverse effects of these drugs have reduced their effectiveness ${ }^{2-5}$.

In general, parasite resistance to medications routinely used in clinical practice has prompted the search for new alternatives, including the use of plant-derived 
extracts containing antiparasitic compounds ${ }^{6,7}$. C. papaya stands out among the plants used for the production of folk medicines due to its anthelmintic action, as established in a preliminary survey about the control of intestinal parasites in Africa ${ }^{8}$. The anthelmintic activity of this plant has been attributed to carpasemine, carpaine-like alkaloids and seed glucosinolates that yield benzyl isothiocyanate, which exert ovicidal and larvicidal effects ${ }^{9,10}$. C. papaya latex and purified papain are effective against $S$. venezuelensis eggs and larvae and can be used as therapeutic alternatives for the control of strongyloidiasis ${ }^{7}$. Considering the anthelmintic potential of $C$. papaya against other gastrointestinal nematodes, the present study aims to examine the in vitro ovicidal and larvicidal activity of C. papaya seeds hexane extract against $S$. venezuelensis.

\section{MATERIALS AND METHODS}

\section{S. venezuelensis eggs and larvae}

The S. venezuelensis strain used in this study was maintained by serial passages of infective larvae (L3) in Wistar rats (Rattus novergicus) by subcutaneous inoculation. The Ethics Committee for Animal Use of the Universidade Federal de Uberlandia (Uberlandia, MG, Brazil) approved the study (protocol $\mathrm{N}^{\circ} 075 / 2008$ ). Faeces from infected animals were used for egg collection and charcoal culture $\left(72 \mathrm{~h}\right.$ at $\left.28^{\circ} \mathrm{C}\right)$ to obtain infective larvae (L3) through the Rugai method ${ }^{11}$.

\section{Preparation of $C$. papaya seed extract}

The Botany Laboratory of the Universidade Federal de Goias (Jatai, GO, Brazil) confirmed the identity of the commercially available mature $C$. papaya fruits used in this study. They corresponded to the C. papaya species deposited at the Herbario Jataiense (Jatai, GO, Brazil, voucher $\mathrm{N}^{\circ}$ 981). Approximately $80 \mathrm{~g}$ of $C$. papaya seeds were removed from mature fruits, washed with water to remove pulp residues and dried at room temperature for five days. Then, about $76 \mathrm{~g}$ of dry seeds were crushed in a crucible and submitted to extraction in a Soxhlet apparatus for $24 \mathrm{~h}$ at $68{ }^{\circ} \mathrm{C}$, using hexane as a solvent. After filtration through filter paper, the filtrate was transferred to a rotary evaporator at $50{ }^{\circ} \mathrm{C}$ to remove the solvent (hexane). The crude seed extract was serially diluted in phosphate buffered saline (PBS) to prepare concentrations ranging from $566 \mathrm{mg} / \mathrm{mL}$ to $0.0566 \mathrm{mg} / \mathrm{mL}$.

\section{Egg hatching test}

The ovicidal activity of the crude extract was analysed using the egg hatching test reported by Coles et $a .^{12}$, with some modifications. Faeces from rats infected with S. venezuelensis were homogenized in water and filtered through a $50 \mu \mathrm{m}$ sieve. After $15 \mathrm{~min}$ of sedimentation, the number of eggs was counted using an optical microscope and the concentration of the suspension was adjusted to 1 egg per $\mu \mathrm{L}$ of filtrate. Then, $50 \mu \mathrm{L}$ of the suspension were incubated in Eppendorf tubes with $50 \mu \mathrm{L}$ of the crude seed extract and its dilutions in PBS, for $48 \mathrm{~h}$ at $28^{\circ} \mathrm{C}$. An albendazole solution $(0.025 \mathrm{mg} / \mathrm{mL})^{13}$ was used as the positive control, while filtered water or PBS were used as negative controls. A $10 \%$ formaldehyde solution was added to the mixture and the number of eggs and larvae were counted using an optical microscope at 100 and $400 x$ magnification. To analyse the integrity of the specimens, images were captured at $400 \times$ magnification using a Leica ${ }^{\circledR}$ camera, model DS750. All the tests were performed in triplicate for each concentration.

\section{Larval motility test}

The larval motility test was performed as reported by Cordeiro et al. ${ }^{14}$, with some modifications. S. venezuelensis infective larvae (L3) were recovered from charcoal culture ${ }^{11}$, and the concentration of the suspension was adjusted to 1 larvae per $\mu \mathrm{L}$ of PBS. Then, $100 \mu \mathrm{L}$ of the suspension were transferred to Eppendorf tubes and mixed with $100 \mu \mathrm{L}$ of the crude seed extract and its dilutions in PBS. The ivermectin solution $(0.316 \mathrm{mg} / \mathrm{mL})$ was used as the positive control $^{15}$ and filtered water and PBS were used as negative controls. The samples were incubated in triplicate for 24,48 , and $72 \mathrm{~h}$, at $28^{\circ} \mathrm{C}$, and larval motility was analysed using an optical microscope at $100 \times$ magnification.

\section{Data analysis}

The efficiency of inhibition of egg hatching (EHT) by the extract was calculated using the formula reported by Wood et al..$^{16}$ :

EHT $(\%)=[($ number of eggs $/($ number of eggs + number of larvae) $] \times 100$

The percentage of inhibition of larval motility (LMT) by each extract dilution was calculated using the formula adapted from Al-Rofaai et al. ${ }^{17}$ :

LMT $(\%)=[(\%)$ motility in the treatment group $(\%)$ motility in the negative control $) /(100-(\%)$ motility in the negative control)] $\times 100$. 
Data from both tests were submitted to logarithmic and non-linear regression analyses to determine the extract half-maximal inhibitory concentration $\left(\mathrm{DL}_{50}\right)$. Significant differences among the extract concentrations, the negative controls and the positive control were analysed using the Fisher's exact test. One-way analysis of variance (ANOVA) combined with the Kruskal-Wallis test was used to compare the mobile and total larvae counts after treatment for different periods and with different extract concentrations. Data were analysed using the statistical package of the GraphPad Prism software, version 5.0 for Windows (GraphPad Software Inc. California, USA). Differences among experimental outcomes were considered as statistically significant when $p<0.05$. All the experiments were carried out in triplicate.

\section{RESULTS}

Analysis of the percentage of S. venezuelensis egg hatching indicated that $C$. papaya seed extract at $56.6 \mathrm{mg} / \mathrm{mL}$ and $5.66 \mathrm{mg} / \mathrm{mL}$ had the strongest inhibitory effects on egg hatching: $95.74 \%( \pm 1.77)$ and $92.16 \%( \pm 2.18)$, respectively; these effects were similar to that achieved after treatment with $0.025 \mathrm{mg} / \mathrm{mL}$ albendazole (positive control) (Figure 1A). Treatment with the extract at these dilutions or albendazole inhibited egg hatching more effectively than the negative controls containing water and PBS $(p<0.01)$.

The extract exerted a concentration-dependent inhibitory effect on egg hatching (Figure 1B), and resulted in a $\mathrm{DL}_{50}=78.14 \mathrm{mg} / \mathrm{mL}$. The C. papaya seed extract in its crude form and at a concentration of $566 \mathrm{mg} / \mathrm{mL}$, lysed all
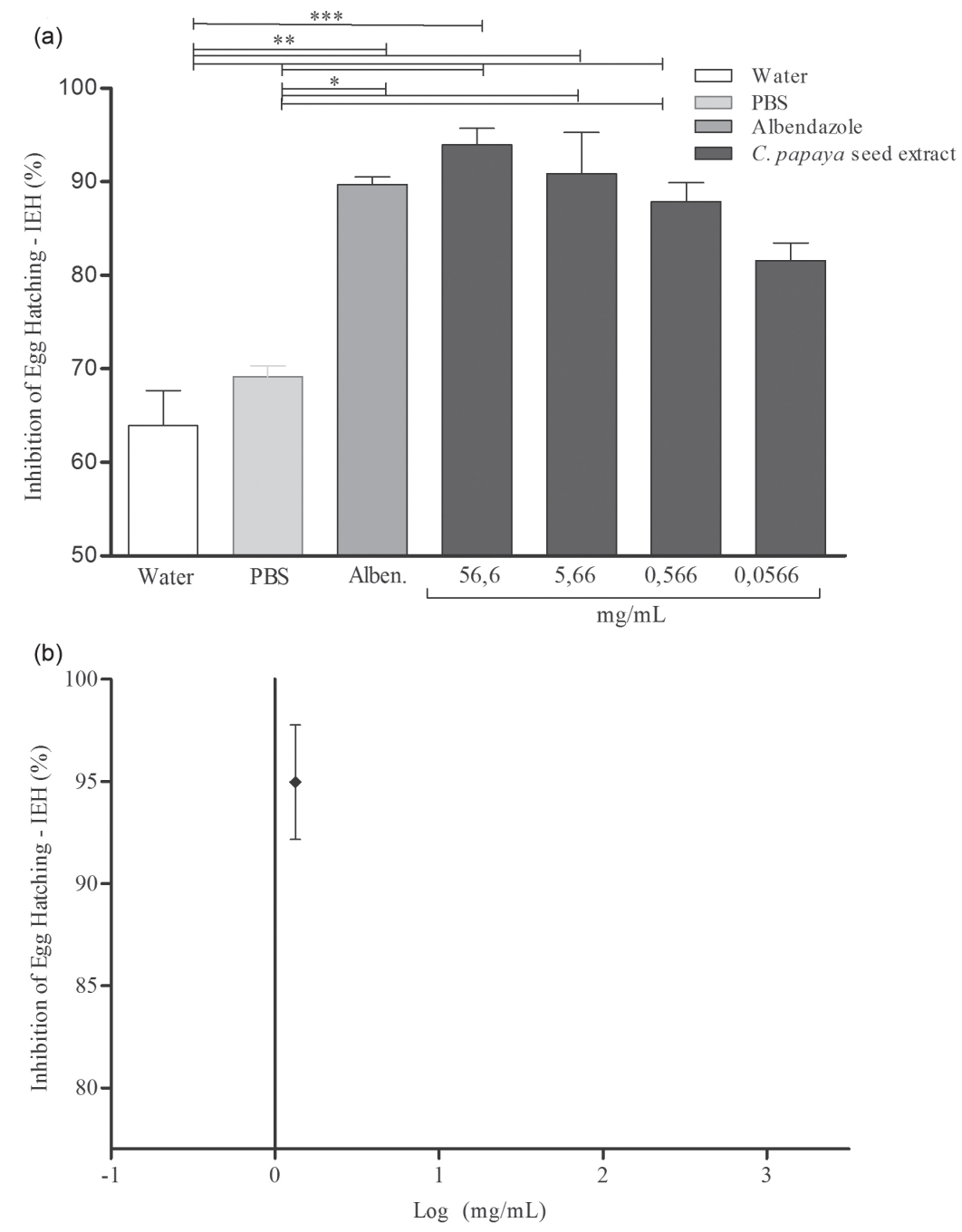

Figure 1 - Inhibition of Strongyloides venezuelensis eggs hatching by Carica papaya seed hexane extract. (A) Percentage of inhibition of eggs hatching determined after treatment of 50 specimens with different extract concentrations $(566-0.0566 \mathrm{mg} / \mathrm{mL})$ for $48 \mathrm{~h}$, at $28^{\circ} \mathrm{C}$. Negative controls: water and PBS. Positive control: albendazole at $0.025 \mathrm{mg} / \mathrm{mL}$. The analysis of TEO efficiency between the concentrations tested and the positive and negative controls was performed by the Fisher's exact test. (B) Non-linear regression curve for inhibition of eggs hatching as a function of extract concentration. Results are expressed as mean \pm standard error of triplicate measurements. ${ }^{*} p<0.05 ;{ }^{* *} p<0.01 ;{ }^{* * *} p<0.0001$. 
or most of the S. venezuelensis specimens when compared with the other dilutions (Figure 2). The inhibitory effects of the extract at concentrations lower than $0.566 \mathrm{mg} / \mathrm{mL}$ were not significantly different from each other $(p>0.05)$.

Larval motility of $S$. venezuelensis L3 larvae was analysed in vitro after 24,48 , and $72 \mathrm{~h}$ of treatment with $C$. papaya seed extract (Figure 3). The extract at $566 \mathrm{mg} / \mathrm{mL}$ and $56.6 \mathrm{mg} / \mathrm{mL}$ suppressed larval motility as effectively as $0.316 \mathrm{mg} / \mathrm{mL}$ of ivermectin (positive control), resulting in $100 \%( \pm 0.0), 97.32 \%( \pm 2.68)$ and $100 \%( \pm 0.0)$, respectively, and was a little more effectively than the extract at $5.66 \mathrm{mg} / \mathrm{mL}(p<0.05)$ (Figure $3 \mathrm{~A})$. Treatment with the extract at $0.566 \mathrm{mg} / \mathrm{mL}$ and $0.0566 \mathrm{mg} / \mathrm{mL}$ inhibited larval motility at percentages similar to those found for the negative controls with water and PBS $(p>0.05): 3.76 \%( \pm 0.5)$ and $5.38 \%( \pm 0.38)$, respectively; these values were significantly lower than that found for the positive control $(p<0.0001)$ (Figure 3A). Hence, high dilutions of the extract did not inhibit $S$. venezuelensis larval motility. It was not possible to count the number of specimens after treatment with the undiluted crude extract.

Figure 3B depicts the concentration-response curve of inhibition of $S$. venezuelensis larval motility as a function of the concentration of $C$. papaya seed extract, after $24 \mathrm{~h}$ of treatment. The extract exerted a statistically significant concentration-dependent effect $(p<0.0001)$, the intensity of which did not vary across the treatment periods; hence, the inhibitory action of the extract on larval motility was not time-dependent. The $\mathrm{DL}_{50}$ value determined at $24 \mathrm{~h}$ of treatment was $20.02 \mathrm{mg} / \mathrm{mL}$. The crude extract lysed all the
S. venezuelensis larvae added to the reaction tube, while the $566 \mathrm{mg} / \mathrm{mL}$ and $56.6 \mathrm{mg} / \mathrm{mL}$ concentrations partially degraded the larvae cuticle, as compared with the negative control containing water (data not shown).

\section{DISCUSSION}

Infections caused by soil-transmitted helminths represent an important public health problem, especially in developing countries ${ }^{18}$. In these locations, the interest in plant-based drugs for the treatment of parasitic diseases has increased progressively for many reasons, including serious side effects caused by the abuse and misuse of synthetic drugs and the difficultly of accessing pharmacological treatment ${ }^{19,20}$.

C. papaya seed extract has demonstrated promising anthelmintic potential against nematodes such as Ascaridia galli, Caenorhabditis elegans, Heterakis gallinarum, Meloidogyne incognita and Pheretima posthuma ${ }^{21,22}$. However, additional studies need to be performed with other human pathogenic parasite species that cause endemic infections in tropical areas throughout the world, such as Strongyloides stercoralis.

The present study demonstrated the in vitro anthelmintic activity of $C$. papaya seeds hexane extract against S. venezuelensis. We found that the extract has effectively suppressed egg hatching and larval motility, in accordance with the standards recommended by the World Association for the Advancement of Veterinary Parasitology ${ }^{16}$. The current in vitro findings with the C. papaya seed extract
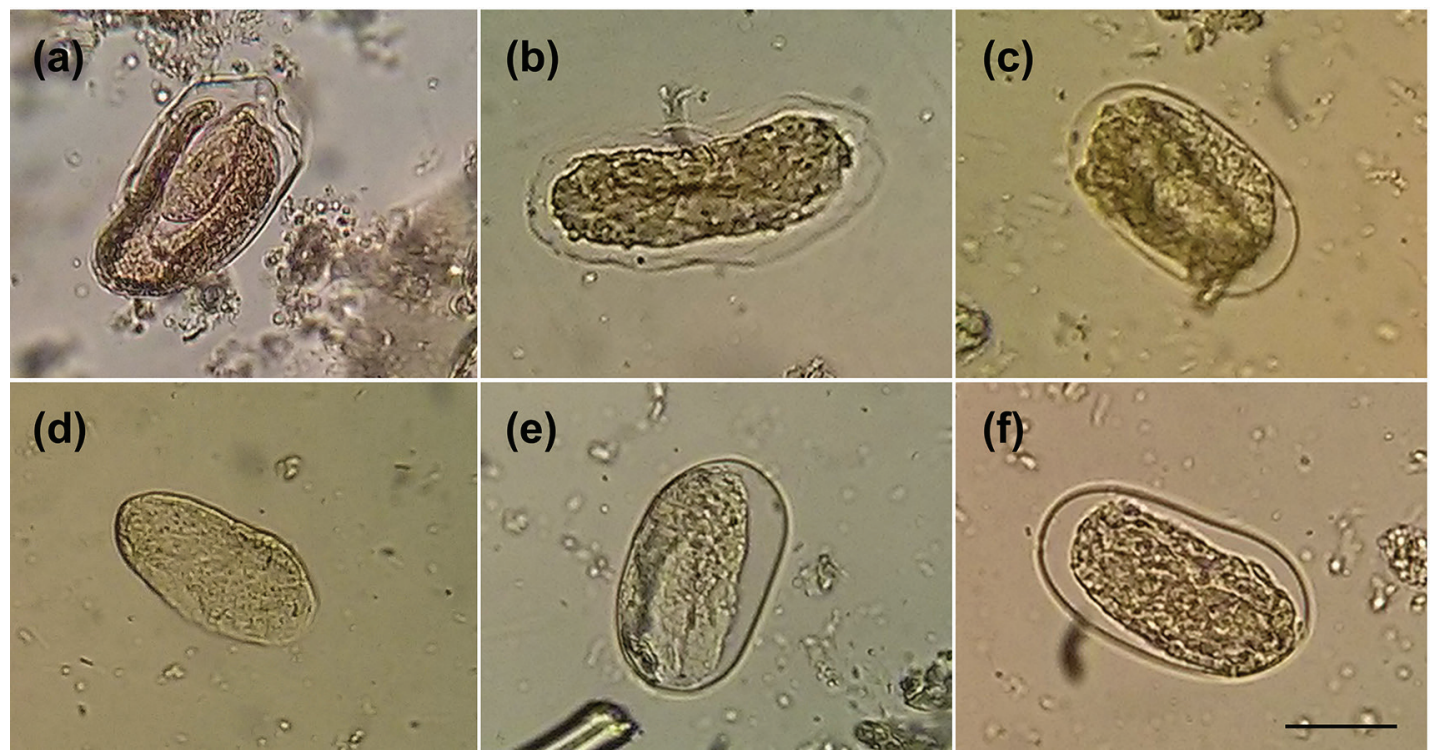

Figure 2 - Effect of Carica papaya seed hexane extract on the development and cuticle integrity of Strongyloides venezuelensis eggs. Fifty specimens were treated with the crude extract (a) or its $566 \mathrm{mg} / \mathrm{mL}$ concentration, (b) $5.66 \mathrm{mg} / \mathrm{mL}$ (c) and $5.66 \mathrm{mg} / \mathrm{mL}$ (d) dilutions, water (e), or PBS (f), for $48 \mathrm{~h}$, at $28^{\circ} \mathrm{C}$. Water and PBS were used as the negative controls. Images were captured at 40x magnification, scale bar $40 \mu \mathrm{m}$. 

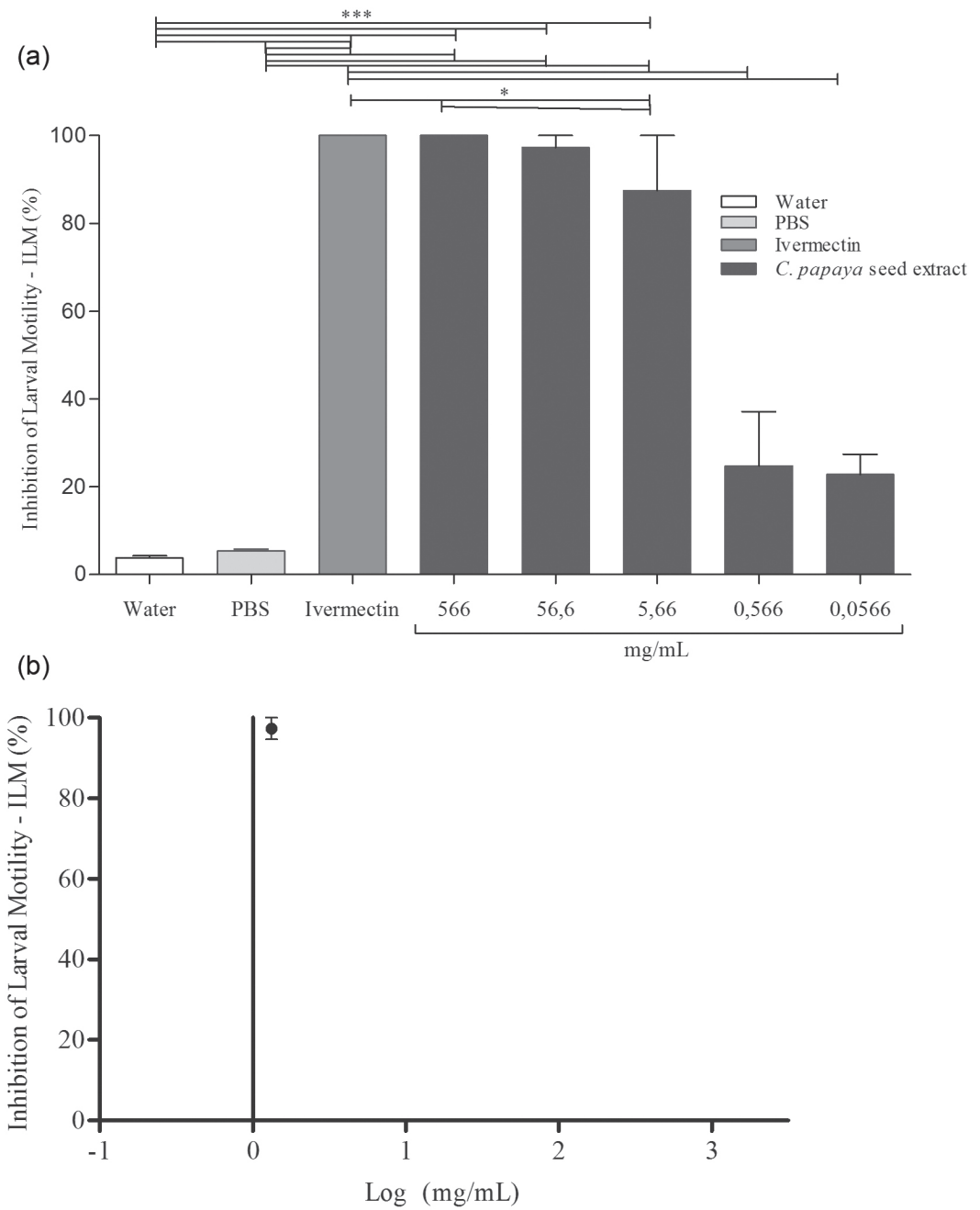

Figure 3 - Inhibition of Strongyloides venezuelensis larvae motility by Carica papaya seed hexane extract. (a) Percentage of inhibition of larval motility determined after treatment of 50 specimens with different extract dilutions for $24 \mathrm{~h}$, at $28^{\circ} \mathrm{C}$. Larval motility was determined by counting mobile and immobile larvae from a total of 50 specimens per sample. Concentrations: $566-0.0566 \mathrm{mg} / \mathrm{mL}$. Negative controls: water and PBS. Positive control: ivermectin at $0.316 \mathrm{mg} / \mathrm{mL}$. One-way analysis of variance (ANOVA) for parametric data and the Kruskal-Wallis test for nonparametric data were used to compare the counts of mobile and total larvae. (B) Non-linear regression curve for inhibition of larval motility as a function of extract concentration. Results are expressed as mean \pm standard error of triplicate measurements. ${ }^{*} p<0.05 ;{ }^{* \star} p<0.01 ;{ }^{* \star \star} p<0.0001$.

are corroborated by literature data on the in vivo effect of this preparation ${ }^{8}$. The aqueous extract of $C$. papaya seeds (i) suppress egg hatching and reduces the number of eggs produced by the nematodes A.galli, H. gallinarum and Trichostrongylus tenuis in infected birds ${ }^{23}$; and (ii) decreases the number of eggs per gram of faeces until the third day after sheep infection with endoparasites, presenting with $72 \%$ efficiency in reducing the parasite $\operatorname{load}^{24}$. The $24 \mathrm{~h}$ treatment with oil from dry and fresh C. papaya seeds is highly efficient in controlling and reducing the lethality of the nematodes $C$. elegans and $M$. incognita; this nematicidal effect seems to be mediated by the oil component benzyl isothiocyanate ${ }^{21}$.

Many anthelmintic glycosides and alkaloids present in $C$. papaya seeds may interfere with the helminth homeostasis by inhibiting glucose uptake, sucrose transfer into the small intestine, nitrate generation, digestion and removal from the cuticle $^{25}$. As helminths cannot store energy, damage to their cuticle leads to muscular paralysis and impairment of larval motility, resulting in parasite death in less than $24 \mathrm{~h}$ due to food deprivation ${ }^{26}$. It is possible that the alkaloid carpaine and the benzyl isothiocyanate present in $C$. papaya seeds exert the anthelmintic effect against the $S$. venezuelensis specimens, but it is necessary to isolate these compounds for new in vitro tests to validate this hypothesis. In any case, the anthelmintic effect of the hexane extract from $C$. papaya seeds against $S$. venezuelensis observed in this study makes it a potential candidate for the development of phytotherapeutic drugs to treat strongyloidiasis. 


\section{ACKNOWLEDGMENTS}

We are grateful to Prof. Dr. Ricardo de Mattos SantaRita from the Laboratorio de Microscopia, Universidade Federal de Goias, Regional Jatai, for his technical skills in gathering microscope images.

\section{AUTHORS' CONTRIBUTIONS}

All authors have made significant contributions to the design, execution, analysis and writing of the study.

\section{CONFLICT OF INTERESTS}

The authors declare that they have no conflict of interests.

\section{REFERENCES}

1. Forrer A, Khieu V, Schär F, Hattendorf J, Marti H, Neumayr A, et al. Strongyloides stercoralis is associated with significant morbidity in rural Cambodia, including stunting in children. PLoS Negl Trop Dis. 2017;11:e0005685.

2. Bisoffi Z, Buonfrate D, Montresor A, Requena-Méndez A, Muñoz J, Krolewiecki AJ, et al. Strongyloides stercoralis: a plea for action. PLoS Negl Trop Dis. 2013;7:e2214.

3. Vadlamudi RS, Chi DS, Krishnaswamy G. Intestinal strongyloidiasis and hyperinfection syndrome. Clin Mol Allergy. 2006;4:8.

4. Amato Neto V, Carignani FL, Matsubara L, Braz LM. Tratamento de ratos, experimentalmente infectados pelo Strongyloides venzuelensis, através da Ivermectina administrada por via oral. Rev Soc Bras Med Trop. 1997;30:481-4.

5. Carranza-Rodríguez C, Mateos-Rodríguez F, Muro A, Arellano JL. Tratamiento antiparasitario. Medicine. 2010;10:3664-72.

6. Hays R, Esterman A, McDermott R. Control of chronic Strongyloides stercoralis infection in an endemic community may be possible by pharmacological means alone: results of a three-year cohort study. PLoS Negl Trop Dis. 2017;11:e0005825.

7. Moraes D, Levenhagen MA, Costa-Cruz JM, Costa Netto AP, Rodrigues RM. In vitro efficacy of latex and purified papain from Carica papaya against Strongyloides venezuelensis eggs and larvae. Rev Inst Med Trop Sao Paulo. 2017;59:e7.

8. Kugo M, Keter L, Maiyo A, Kinyua J, Ndemwa P, Maina G, et al. Fortification of Carica papaya fruit seeds to school meal snacks may aid Africa mass deworming programs: a preliminary survey. BMC Complement Altern Med. 2018;18:327.

9. Krishna KL, Paridhavi M, Patel JA. Review on nutritional, medicinal and pharmacological properties of Papaya (Carica papaya Linn.). Nat Prod Rad. 2018;7:364-73.
10. Kermanshai R, McCarry BE, Rosenfeld J, Summers PS, Weretilnyk EA, Sorger GJ. Benzyl isothiocyanate is the chief or sole anthelmintic in papaya seed extracts. Phytochemistry. 2001;57:427-35.

11. Rugai E, Mattos T, Brisola AP. Nova técnica para isolar larvas de nematoides das fezes: modificações do método de Baermann. Rev Inst Adolfo Lutz. 1954;14:5-8.

12. Coles GC, Bauer C, Borgsteede FH, Geerts S, Klei TR, Taylor MA, et al. World Association for the Advancement of Veterinary Parasitology (W.A.A.V.P.) methods for detection of anthelmintic resistance in nematodes of veterinary importance. Vet Parasitol. 1992;44:35-44.

13. Carvalho CO, Chagas AC, Cotinguiba F, Furlan M, Brito LG, Chaves FC, et al. The anthelmintic effect of plant extract on Haemonchus contortus and Strongyloides venezuelensis. Vet Parasitol. 2012;183:260-8.

14. Cordeiro LN, Athayde AC, Vilela VL, Costa JG, Silva WA, Araujo $\mathrm{MM}$, et al. Efeito in vitro do extrato etanólico das folhas do melão-de-São-Caetano (Momordica charantia L) sobre ovos e larvas de nematoides gastrintestinais de caprinos. Rev Bras Plantas Med. 2010;12:421-6.

15. Rebollo CD, Taira N, Ura S, Williams JC. Larvicidal effects of several chemicals on Strongyloides infective larvae. Vet Parasitol. 2003;118:165-8.

16. Wood IB, Amaral NK, Bairden K, Duncan JL, Kassai T, Malone JB Jr, et al. World Association for the Advancement of Veterinary Parasitology (W.A.A.V.P.) second edition of guidelines for evaluating the efficacy of anthelmintics in ruminants (bovine, ovine, caprine). Vet Parasitol. 1995;58:181-213.

17. Al-Rofaai A, Rahman WA, Abdulghani M. Sensitivity of two in vitro assays for evaluating plant activity against the infective stage of Haemonchus contortus strains. Parasitol Res. 2013;112:893-8.

18. Gebretsadik D, Metaferia Y, Seid A, Fenta GM, Gedefie A. Prevalence of intestinal parasitic infection among children under 5 years of age at Dessie Referral Hospital: cross sectional study. BMC Res Notes. 2018;11:771.

19. Rates SM. Plants as source of drugs. Toxicon. 2001;39:603-13.

20. Martins GN, Silva RF, Araújo EF, Pereira MG, Vieira HD, Viana AP. Influência do tipo de fruto, peso específico das sementes e período de armazenamento na qualidade fisiológica de sementes de mamão do grupo formosa. Rev Bras Sementes. $2005 ; 27: 12-7$.

21. Nagesh M, Chandravadana MV, Sreeja VG, Bujji-Babu CS. Benzyl isothiocyanate from Carica papaya seeds: a potential nematicide against Meloidogyne incognita. Nematol Medit. 2002;30:155-7.

22. Ameen SA, Adedeji OS, Ojedapo LO, Salihu T, Fabusuyi CO. Anthelmintic potency of pawpaw (Carica papaya) seeds in West African Dwarf (WAD) sheep. Glob Vet. 2010;5:30-4. 
23. Rupa S, Jayanta B. Comparative studies on anthelmintic potential of Cucurbita maxima (Pumpkin) seeds and Carica papaya (Papaya) seeds. Int J Res Ayurveda Pharm. 2013;4:530-2.

24. Pereira JS, Pessoa HF, Bessa EN, Nascimento JO, Coelho WA, Fonseca ZA, et al. Avaliação do extrato de semente de mamão formosa (Carica papaya, Linnaeus) no controle de endoparasitas de ovinos no Rio Grande do Norte, Brasil. Acta Vet Bras. 2013;7:48-51.
25. Bi S, Goyal PK. Anthelmintic effect of natural plant (Carica papaya) extract against the gastrointestinal nematode Ancylostoma caninum in mice. ISCA J Biol Sci. 2012;1:2-6.

26. Sireesha R, Raju KL, Rao CL, Babu KK, Pushpalatha B, Sandeep $\mathrm{D}$, et al. In vitro anthelmintic activity of different solvent extracts of Sesamum indicum seeds. IJCPS. 2013;2:1208-12. 